\title{
DIAGNOSIS KEBUNTINGAN KUDA MENGGUNAKAN KIT MARE TEST PACK
}

\author{
Pregnancy Diagnosis on Mares Using Mare Test Pack Kit
}

\author{
Ali Saifudin', Siti Aslimah', Lia Nur Aini' ${ }^{1}$, dan Theo Mahiseta Syahniar ${ }^{2}$ \\ ${ }^{1}$ Program Studi Produksi Ternak, Politeknik Pertanian dan Peternakan Mapena \\ 2Jurusan Peternakan, Politeknik Negeri Jember \\ Email: ali.saifudin@gmail.com
}

\begin{abstract}
INTISARI
Penelitian ini bertujuan untuk mendiagnosis kebuntingan pada kuda menggunakan kit mare test pack (MTP). Penelitian ini menggunakan 10 kuda yang telah dipastikan status kebuntingannya dengan teknik eksplorasi rektal (gold standard) yang terdiri dari tujuh kuda bunting (K1) dan tiga kuda tidak bunting (K2). Serum dari kedua kelompok kemudian diuji menggunakan kit MTP. Data hasil penelitian diuji secara deskriptif. Hasil penelitian menunjukkan bahwa tujuh kuda yang positif bunting setelah diuji dengan menggunakan kit MTP menunjukkan bunting dan tiga kuda yang negatif menunjukkan tidak bunting dengan eksplorasi rektal. Hasil penelitian ini dapat disimpulkan bahwa kit MTP dapat digunakan untuk mendiagnosis kebuntingan pada kuda umur 60 sampai 100 hari kebuntingan dengan sensitivitas dan spesifisitas dengan akurasi $100 \%$.
\end{abstract}

Kata kunci: Diagnosis Kebuntingan, Kuda, Kit MTP, eCG, Metode HI

ABSTRACT

This research aimed to diagnosed pregnancy on mares using a test mare (MTP) kit. This study using 10 mares were used to confirm their pregnancy status using a rectal exploration technique (gold standard) using seven pregnant mares (K1) and three non-pregnant mares (K2). Serums from both groups were tested using a MTP kit. The research data were tested descriptive. The results showed that seven mares that were positively pregnant and three negative mares unpregnant after being tested using the MTP kit and rectal exploration. The conclusion that the MTP kit can be used to diagnose pregnancy in mares of 60 to 100 pregnancy days which is 100\% accuracy sensitivity and specificity.

Keywords: Pregnancy Diagnosis, Mare, MTP Kit, eCG, HI Method

\section{PENDAHULUAN}

Perkembangan populasi kuda di Indonesia belum mencapai keadaan yang menggembirakan bahkan secara nasional pada tahun 2017 terjadi penurunan populasi ternak kuda sebesar 400 ribu ekor atau 1,43\% (Ditjen PKH, 2017). Beberapa kendala yang menghambat perkembangan populasi kuda adalah waktu birahi yang panjang, keguguran, dan diagnosis kebuntingan dini. Hal ini ditunjukkan dengan adanya gejala birahi yang sulit dilakukan karena 15\% kuda bunting masih menunjukkan gejala birahi (Mahaputra, 1994; McKinnon, et al., 2011). Kendala lain yang sering dihadapi peternak kuda adalah panjangnya calving interval dan rendahnya tingkat kebuntingan sehingga upaya untuk mencapai tingkat reproduktivitas yang tinggi sulit dicapai. Target reproduktivitas yang tinggi dapat dicapai dengan melakukan perbaikan pengelolaan reproduksi yang meliputi deteksi birahi, perkawinan, dan diagnosis kebuntingan yang tepat.

Diagnosis kebuntingan dini diperlukan setelah terjadinya perkawinan, yaitu dengan identifikasi lebih awal pengukuran tingkat reproduktivitas kuda sehingga kehilangan waktu produksi sebagai akibat infertilitas dapat dikurangi (Hafez dan Hafez, 2008). 
Diagnosis kebuntingan yang akurat adalah kunci utama untuk penanganan kuda bunting muda. Ketika kebuntingan dapat dipastikan, penanganan manajemen kuda bunting akan lebih optimal (Morel, 2003).

Diagnosis kebuntingan dini pada kuda secara imunologis dapat dilakukan dengan dua cara, yaitu dengan mendeteksi substansi spesifik yang terdapat di dalam darah induk seperti equine chorionic gonadotropin (eCG), early pregnancy factor (EPF), dan dengan mendeteksi substansi non spesifik yang ada di dalam darah, urine atau air susu selama kebuntingan seperti progesterone dan estrogen (Hafez dan Hafez, 2008).

Hormon gonadotropin yang hanya dimiliki oleh kuda umur kebuntingan 40 sampai 150 hari adalah eCG. Kit diagnostic dikembangkan untuk dapat melihat substansi spesifik eCG yang dalam penelitian ini menggunakan metode haemagglutination inhibition (HI) yang dapat dilakukan secara cepat dan mudah (Hunter, 1994; Samper et al., 2007). Diagnosis kebuntingan dengan eCG metode HI adalah suatu pengembangan metode yang didasarkan pada reaksi antigen, antibody, dan eritrosit domba yang telah disensitifkan dengan eCG (Wide dan Wide, 1963). Kit eCG metode HI komersil belum banyak digunakan di Indonesia. Kit ini digunakan dengan nama mare immunological pregnancy test (MIP Test) (Hafez dan Hafez, 2008). Kit ini biasa digunakan oleh breeder yang tidak mempunyai akses teknologi atau ahli pada ultrasound dan teknik palpasi. Penelitian ini bertujuan untuk mendiagnosis kebuntingan pada kuda menggunakan kit mare test pack (MTP) dengan hormon yang spesifik pada kuda bunting (eCG). Kit ini diharapkan menjadi salah satu alternatif tes kebuntingan pada kuda.

\section{MATERI DAN METODE}

Penelitian ini terdiri dari tiga tahap. Pertama, pengambilan dan persiapan sampel serum darah kuda. Kedua, pembuatan kit MTP dan ketiga pengujian MTP. Kuda yang digunakan dalam penelitian ini adalah kuda Thoroughbred sebanyak 10 ekor yang telah dipastikan status kebuntingannya dengan teknik eksplorasi rektal (gold standard). Kuda terbagi menjadi dua kelompok. Kelompok pertama (K1) terdiri dari tujuh ekor kuda bunting (umur kebuntingan 2 sampai 3 bulan). Kelompok kedua (K2) terdiri dari tiga ekor kuda tidak bunting.

\section{Pengambilan dan Persiapan Sampel Serum Darah Kuda}

Darah kuda diambil dari vena jugularis dengan menggunakan disposable syringe 50 $\mathrm{ml}$, kemudian ditampung dalam tabung reaksi dan ditutup. Tabung tersebut dimiringkan $45^{\circ}$ dan didiamkan selama 24 jam pada suhu kamar, kemudian disentrifus dengan kecepatan 3000 rpm selama 10 menit. Serum yang didapat disaring menggunakan miliphore $0,22 \mu \mathrm{m}$. Serum ditampung pada vial dan disimpan dalam freezer dengan suhu $-20^{\circ} \mathrm{C}$ atau dimasukkan dalam tabung reaksi dan ditambahkan metanol dengan perbandingan 1:5 lalu dikocok selama 3 menit kemudian didiamkan 15 sampai 20 menit sampai terdapat 2 lapisan cairan. Supernatan diambil dengan disposable syringe sebanyak $5 \mathrm{ml}$ dan dimasukkan dalam vial $10 \mathrm{ml}$ untuk dibuat sediaan kering beku. Serum yang didapat perlu ditambahkan PBS sebanyak $5 \mathrm{ml}$ sebelum digunakan untuk uji selanjutnya.

\section{Pembuatan Kit Mare Test Pack (MTP)}

Kit terdiri atas 2 bahan yaitu eritrosit domba yang telah disensitifkan dengan eCG dan antibodi poliklonal anti eCG. Antibodi poliklonal yang digunakan dalam penelitian ini diperoleh dari penelitian sebelumnya, yaitu titer antibodi dengan pengenceran tertinggi yang masih dapat menyebabkan terjadinya komplit aglutinasi dari sel dengan titer 1:200. Eritrosit domba yang telah disensitifkan dengan eCG dalam penelitian ini mengacu pada Wide (1962) yang terdiri dari beberapa tahap.

\section{Pemberian antikoagulan terhadap sediaan eritrosit}

Eritrosit yang digunakan adalah eritrosit domba. Sediaan eritrosit domba sebanyak $100 \mathrm{ml}$ dimasukkan ke dalam tabung yang sudah berisi larutan alsever 110 $\mathrm{ml}$, disentrifus 600 sampai $1.000 \mathrm{G}$ kemudian dicuci 3 sampai 4 kali dalam 8 sampai 10 volume salin.

\section{Perlakuan dengan stabilizing reagents}

Stabilizing reagents dibuat dengan cara menambahkan $0,1 \mathrm{~N} \mathrm{NaOH}$ ke dalam larutan 
formalin 37\% (agar pHnya menjadi 7 sampai 7,5), kemudian diencerkan sampai 3\% dengan salin. Satu volume stabilizing reagents dicampur dengan satu volume dari 8\% larutan eritrosit domba yang telah diberikan antikoagulan, kemudian diinkubasi pada suhu $37^{\circ} \mathrm{C}$ selama 18 sampai 24 jam. Setelah diinkubasi eritrosit dicuci 4 kali dengan 8 sampai 10 volume air destilasi, kemudian disimpan pada suhu $4^{\circ} \mathrm{C}$ di larutan $10 \%$ air destilasi.

\section{Penyamakan eritrosit dengan tannic acid}

Satu volume dari eritrosit yang telah diformalin dicuci 3 kali pada 50 volume larutan phosphate buffered saline (PBS). Suspensi pada larutan tannic acid diinkubasi pada water bath dengan konsentrasi tannic acid 1/40.000 (pada pH 6,4 dalam PBS, suhu $56^{\circ} \mathrm{C}$, konsentrasi eritrosit $2 \%$, dan waktu 30 menit).

\section{Pengadsorbsian eCG pada eritrosit}

Setelah eritrosit disamak, dicuci 2 kali dengan larutan PBS 50 volume, kemudian ditambahkan eCG $100 \mathrm{IU} / \mathrm{ml}$ (pada $\mathrm{pH}$ 6,4 dalam PBS, suhu $56^{\circ} \mathrm{C}$, konsentrasi eritrosit 4\%, dan waktu 120 menit). Setelah terserap, dicuci 3 kali dengan 50 volume larutan PBS $\mathrm{pH}$ 6,4 dan disimpan dalam 2,5\% larutan yang berisi $0,2 \%$ serum darah kelinci normal.

\section{Pengujian Kit MTP}

Serum kuda yang telah diekstraksi dengan metanol, diambil sebanyak 0,25 ml larutan supernatan, dimasukkan ke dalam microtube, kemudian ditambahkan antibodi poliklonal anti eCG sebanyak $0,25 \mathrm{ml}$ dan ditambahkan lagi $0,25 \mathrm{ml}$ eritrosit domba yang tersensitisasi ke dalam microtube tersebut. Campuran tersebut diinkubasi pada suhu $37^{\circ} \mathrm{C}$ selama 120 menit. Hasil reaksi positif bunting jika ada eCG dalam serum kuda yang ditandai dengan terjadi hambatan aglutinasi eritrosit (adanya endapan pada dasar microtube). Hasil negatif atau tidak bunting bila tidak ada eCG yang ditandai dengan terjadi aglutinasi (adanya gumpalan berbentuk titik butiran pasir).

\section{Analisa Diagnosability Kit MTP}

Hasil dari diagnosis kebuntingan menggunakan kit MTP dibandingkan dengan metode diagnosis eksplorasi rektal sebagai gold standard. Diagnosability yang diamati adalah sensitivitas dan spesifisitas. Sensitivitas (true positive) adalah probabilitas dimana kit MTP menunjukkan hasil yang positif bunting dan kuda benar-benar bunting setelah diujikan dengan gold standard, kebalikannya adalah false negative yaitu kit menunjukkan hasil tidak bunting padahal kuda bunting. Spesifisitas (true negative) adalah probabilitas dimana kit MTP menunjukkan hasil yang positif tidak bunting dan kuda benar-benar tidak bunting setelah diujikan dengan gold standard dan kebalikannya adalah false positive yaitu kit menunjukkan hasil bunting padahal kuda tidak bunting (Diane, 1995). Rumus sensitivitas dan spesifisitas dijelaskan dalam persamaan menurut Akobeng (2006).

\section{Sensitivity $=\frac{\text { true positive }}{\text { true positive }+ \text { false negative }} \times 100 \%$}

Specificity $=\frac{\text { true negative }}{\text { true negative }+ \text { false positive }} \times 100 \%$

\section{HASIL DAN PEMBAHASAN}

Hasil uji kit MTP pada serum darah kuda dapat dilihat pada Gambar 1 dan Gambar 2 serta pada Tabel 1 berikut.

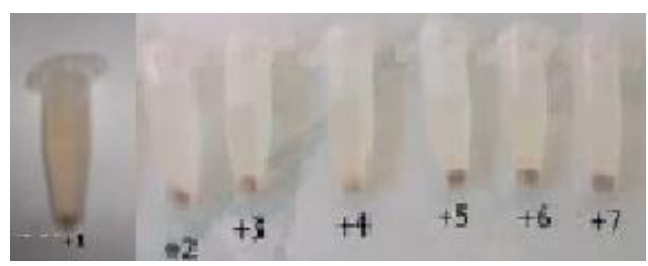

Gambar 1. Kelompok 1 (K1)

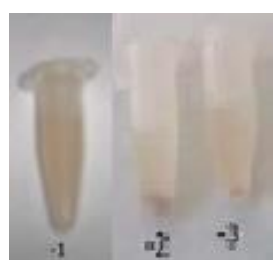

Gambar 2. Kelompok 2 (K2)

Gambar 1 dan Gambar 2 serta Tabel 1 menunjukkan hasil bahwa pada serum kuda K1 terjadi hambatan aglutinasi. Hal tersebut ditandai atau terlihat dengan adanya endapan pada dasar microtube yang menandakan kuda bunting dan apabila digoyangkan ke bawah 
seperti tetesan air mata. Pada dasar microtube K2 terjadi aglutinasi yang ditandai dengan adanya gumpalan berbentuk titik butiran pasir yang menunjukkan bahwa kuda tidak bunting. Hasil uji menggunakan kit MTP tersebut kemudian dibandingkan dengan uji ekslporasi rektal untuk mengetahui tingkat kesesuaiannya (Tabel 2).

Tabel 1. Hasil Uji Kebuntingan Menggunakan Kit MTP

\begin{tabular}{cccc}
\hline Kelompok Kuda & Recording Tube & Uji MTP & Keterangan \\
\hline & +1 & Hambatan aglutinasi & Bunting \\
& +2 & Hambatan aglutinasi & Bunting \\
& +3 & Hambatan aglutinasi & Bunting \\
K1 & +4 & Hambatan aglutinasi & Bunting \\
& +5 & Hambatan aglutinasi & Bunting \\
& +6 & Hambatan aglutinasi & Bunting \\
& +7 & Hambatan aglutinasi & Bunting \\
\hline & -1 & Aglutinasi & Tidak bunting \\
K2 & -2 & Aglutinasi & Tidak bunting \\
& -3 & Aglutinasi & Tidak bunting \\
\hline
\end{tabular}

K1 : Kelompok kuda bunting, hasil eksplorasi rektal

K2 : Kelompok kuda tidak bunting, hasil eksplorasi rektal

Hasil perbandingan uji kit MTP dengan eksplorasi rektal (Tabel 2) diketahui bahwa hasil uji terhadap sampel K1 dan K2 menunjukkan hasil yang berbeda. Kelompok pertama setelah diuji dengan MTP menunjukkan hasil positif bunting 100\%. Kelompok kedua setelah diuji dengan MTP juga menunjukkan hasil tidak bunting $100 \%$. Hasil yang berbeda ini sesuai dengan Morel (2003) yang menyatakan bahwa akurasi positif bunting tes adalah 60 sampai 100\% dan pemeriksaan kejadian tidak bunting mempunyai akurasi $100 \%$.

Hasil positif bunting atau true positive 100\% menunjukkan sensitivitas kit MTP dan hasil tidak bunting atau true negative 100\% menunjukkan spesifisitas kit MTP. Hasil dari sensitivitas dan spesifisitas $100 \%$ dapat dimungkinkan terjadi karena jenis bangsa kuda yang digunakan dalam uji kebuntingan penelitian ini. Kebuntingan pada keledai (jack $\mathrm{X}$ jenny) atau pada bagal (mare $\mathrm{X}$ jack) endometrial cup-nya kecil dan menghasilkan eCG dalam jumlah yang sangat sedikit sehingga tes imunologi eCG pada kebuntingan keledai dan bagal menunjukkan level yang sangat rendah (Evan, 1992). Penelitian ini menggunakan kuda jenis Thoroughbred sehingga hasilnya signifikan dalam hal ini sensitivitas dan spesifitas $100 \%$.

Faktor lain yang menyebabkan hasil yang berbeda pada penelitian ini adalah umur kebuntingan kuda yang digunakan. Kuda bunting yang digunakan dalam penelitian ini berumur 60 sampai 90 hari kebuntingan. Hal ini sesuai dengan pernyataan Hafez dan Hafez (2008) bahwa kit eCG metode HI tes paling akurat dilakukan pada 50 sampai 100 hari kebuntingan. Konsentrasi eCG berada dalam puncaknya pada 60 sampai 70 hari kebuntingan dan mulai menurun pada 120 hari kebuntingan (Morel, 2003). Menurut Noakes et al. (2001) eCG metode HI akurasinya $95 \%$ bila diujikan pada kuda umur 40 sampai 110 hari, sehingga dapat dinyatakan pada penelitian ini menggunakan umur kebuntingan yang tepat sekitar 60 sampai 90 hari, dimana eCG masih berada dalam konsentrasi maksimum.

Hormon eCG diproduksi oleh endometrial cup. Awal terdeteksi pada 38 sampai 42 hari kebuntingan dan mulai meningkat dengan cepat sampai level maksimum yaitu 50 sampai $200 \mathrm{IU} / \mathrm{ml}$ pada 50 sampai 70 hari kebuntingan. Konsentrasi tersebut menurun hingga menghilang pada umur 110 sampai 140 hari kebuntingan. Beberapa kuda memproduksi konsentrasi eCG maksimum hanya $10 \mathrm{IU} / \mathrm{ml}$ dan tidak terdeteksi lagi setelah 80 hari kebuntingan (Noakes, et al., 2001). Pada kuda bunting, eCG dapat dideteksi dengan metode $\mathrm{HI}$, apabila serum kuda mengandung 1,6 IU/ml eCG (Wide dan Wide, 1963), sehingga paling akurat eCG metode HI digunakan pada 60 sampai 70 hari kebuntingan atau selambatlambatnya sebelum 80 hari kebuntingan karena konsentrasi eCG masih tinggi. 
Tabel 2. Hasil Perbandingan Uji Kit MTP dengan Eksplorasi Rektal

\begin{tabular}{llcc}
\hline \multirow{2}{*}{ Uji } & \multicolumn{1}{c}{ Hasil Uji } & \multicolumn{2}{c}{ Kelompok Kuda } \\
\cline { 3 - 4 } Kit MTP & Hambatan aglutinasi (bunting) & 7 ekor & K2 \\
\hline \multirow{2}{*}{ Eksplorasi Rektal } & Aglutinasi (tidak bunting) & - & 3 ekor \\
\hline & Bunting & 7 ekor & - \\
& Tidak bunting & - & 3 ekor \\
\hline
\end{tabular}

Kelompok pertama, setelah dilakukan uji kebuntingan dengan MTP, hasil positif bunting ditunjukkan dengan hambatan aglutinasi, yaitu antibodi anti eCG tidak berikatan dengan indikator dalam hal ini eritrosit domba yang telah disensitifkan dengan eCG melainkan berikatan dengan antigen yaitu serum kuda yang mengandung eCG. Serum darah pada kuda bunting mengandung eCG. eCG merupakan substansi spesifik yang hanya dimiliki oleh kuda bunting. eCG terdeteksi dalam serum kuda bunting melalui uji metode HI yang ditandai dengan terjadinya hambatan aglutinasi. Kuda dapat dipastikan kebuntingannya apabila terjadi hambatan aglutinasi yang berarti terdapat eCG dalam serum kuda . Kelompok kedua, setelah dilakukan uji kebuntingan dengan MTP, hasilnya menunjukkan terjadinya aglutinasi, yaitu antibodi anti eCG berikatan dengan indikator berupa eritrosit domba yang telah disensitifkan dengan eCG. Pada kuda tidak bunting, serumnya tidak terdapat eCG, sehingga terjadi aglutinasi, dan kuda dapat dipastikan tidak bunting (Wide dan Wide, 1963; Hafez dan Hafez, 2008).

Metode HI yang digunakan termasuk uji pengikatan sekunder yaitu uji yang mengukur akibat pembentukan imunokomplek in vitro, dalam hal ini khususnya aglutinasi pasif. Aglutinasi pasif adalah salah satu cara yang dilakukan dengan pengikatan kimiawi antigen terlarut dengan partikel lembam seperti eritrosit, bakteri atau latex, sehingga antibodi khusus akan menyebabkan partikel yang telah disensitisasi ini beraglutinasi. Eritrosit merupakan partikel terbaik diantara partikel lainnya untuk tujuan ini. Uji yang menggunakan eritrosit terlapis dinamakan uji hemaglutinasi pasif. Pada penelitian ini menggunakan eritrosit domba yang telah disensitisasi dengan eCG.

Kit penelitian ini memiliki banyak keunggulan apabila dibandingkan dengan diagnosis kebuntingan lain pada kuda, misalnya eksplorasi rektal (Hunter, 1995). Kit penelitian ini tidak memerlukan keahlian khusus untuk melakukannya, sesuai yang dikatakan Mahaputra (2002) bahwa syarat diagnosis kebuntingan salah satunya adalah dapat dilakukan oleh siapa saja atau dalam istilah Morel (2003) disebut uncomplicated. Kit penelitian ini biasanya digunakan oleh breeder yang tidak mempunyai akses teknologi atau ahli pada ultrasound dan eksplorasi rektal. Penggunaan kit penelitian ini tidak tergantung dari jumlah kuda yang akan diujikan, artinya jumlah kuda yang digunakan sedikit atau banyak tetap efisien untuk dilakukan. Kit penelitian ini relatif singkat untuk dilakukan, yaitu reaksi akan terbaca setelah 1,5 sampai 2 jam (Wide dan Wide, 1963).

Parameter yang diamati pada penelitian ini adalah sensitivitas dan spesifisitas kit MTP. Sensitivitas dan spesifisitas pada MTP sebagai kit dalam penelitian ini didapatkan melalui perbandingan dengan eksplorasi rektal sebagai gold standard. Gold standard yang digunakan sesuai pendapat Diane (1995) yaitu tes yang sederhana dan relatif tidak mahal.

Sensitivitas pada kit MTP hasilnya $100 \%$ dan tergolong sensitivitas tinggi. Tes yang mempunyai sensitivitas tinggi berguna untuk screening kebuntingan kuda (Diane, 1995). Kegunaan kit MTP adalah untuk memastikan kebuntingan, sehingga kuda yang telah dipastikan bunting untuk perawatan dan manajemen selanjutnya dapat dilakukan sedini mungkin, sehingga kekhawatiran untuk terjadinya abortus dapat dihindari dan untuk kuda yang tidak bunting maka prosedur untuk mengawinkannya kembali atau mengevaluasi mengapa tidak terjadi kebuntingan dapat dilakukan (Diane, 1995; Hafez dan Hafez, 2008). Tes yang mempunyai sensitivitas tinggi sedikit terjadi false negative. Ketika hasil tes menyatakan kuda tidak bunting maka praktisi dapat memastikan kuda memang tidak 
bunting, sehingga tes yang mempunyai sensitivitas yang tinggi sangat membantu ketika hasilnya negatif atau tidak bunting (Diane, 1995). Sesuai dengan pernyataan Morel (2003) bahwa pemeriksaan kejadian tidak bunting akurasinya $100 \%$.

Spesifisitas kit MTP juga 100\% dan tergolong spesifisitas tinggi. Tes yang mempunyai spesifisitas yang tinggi hasil false positive kecil. Konsekuensinya tes yang spesifik sangat membantu ketika hasilnya positif atau bunting (Diane, 1995). Indonesia yang merupakan negara berkembang, di samping kehandalan dan kepraktisan dari suatu tes, biaya pemeriksaan merupakan faktor yang perlu diperhitungkan dalam pemilihan tes. Suatu uji laboratoris yang sangat handal tetapi tidak praktis dan membutuhkan biaya pemeriksaan yang mahal hanya mempunyai arti akademis dan hanya dapat digunakan untuk penelitian tetapi tidak dapat digunakan untuk keperluan pelayanan di lapangan (Handojo, 1996). Kit MTP ini diharapkan menjadi salah satu alternatif bahan diagnosis untuk tes kebuntingan pada kuda yang relatif murah dan mudah digunakan.

\section{KESIMPULAN}

Hasil penelitian menunjukkan bahwa tujuh kuda yang positif bunting setelah diuji dengan menggunakan kit MTP menunjukkan bunting dan tiga kuda yang negatif menunjukkan tidak bunting dengan eksplorasi rektal. Hasil penelitian ini dapat disimpulkan bahwa kit MTP dapat digunakan untuk mendiagnosis kebuntingan pada kuda umur 60 sampai 100 hari kebuntingan dengan sensitivitas dan spesifisitas dengan akurasi $100 \%$.

\section{DAFTAR PUSTAKA}

Akobeng, A.K. 2006. Understanding diagnostic test 1: sensitivity, specificity, and predictive values. Acta Pædiatrica. 96(3):338-341.

Diane, E.S. 1995. Examination and Board Review Medical Biostatistics and Epidemiology. $1^{\text {st }}$ ed. Appleton and Lange. Connecticut.

Ditjen P.K.H. 2017. Statistik Peternakan dan Kesehatan Hewan. Direktorat Jenderal
Peternakan dan Kesehatan Hewan. Kementerian Pertanian. Jakarta.

Hafez, E.S.E. and B. Hafez. 2008. Reproduction in Farm Animals. $7^{\text {th }}$ ed. Blackwell. Philadelphia.

Handojo, I. 1996. Diktat Kuliah untuk PPDS I PK Imunoasai I-IV. Lab. Patologi Klinik Fakultas Kedokteran Universitas Airlangga. Surabaya.

Hunter, R.P.F. 1995. Fisiologi dan Teknologi Reproduksi Hewan Betina Domestik. Penerbit ITB. Bandung.

Mahaputra, L. 2002. Teknik Diagnosis Reproduksi. Edisi I Cetakan Ke-3. Fakultas Kedokteran Hewan Universitas Airlangga. Surabaya.

Mahaputra, L. 1994. Ilmu Kebidanan Veteriner. Edisi Lima. Fakultas Kedokteran Hewan Universitas Airlangga. Surabaya.

McKinnon, A.O., Squires, E.L., Vaala, W.E. and D.D. Varner. 2011. Equine Reproduction. $2^{\text {nd }}$ ed. Wiley-Blackwell. West Sussex.

Morel, D.M.C.G. 2003. Equine Reproductive Physiology, Breeding and Stud Management. $2^{\text {nd }}$ ed. CABI Publishing. London.

Noakes, D.E., T.J. Parkinson, and G.C.W. England. 2001. Arthur's Veterinary Reproduction and Obstetrics. $8^{\text {th }}$ ed. Saunders, Philadelphia.

Samper, J.C., Pycock, J.F. and A.O. McKinnon. 2007. Current Therapy in Equine Reproduction. Saunders. Missouri.

Wide, L. 1962. An immunologic method for the assay of human chorionic gonadotrophin. Acta Endocrinologica. 41(Suppl. 70):20-27.

Wide, M. and L. Wide. 1963. Diagnosis of pregnancy in mares by an immunological method. Nature. 198: 1017-1018. 